Premiere Educandum: Jurnal Pendidikan Dasar dan Pembelajaran

Volume 11 (2) 215 - 226 December 2021

ISSN: 2088-5350 (Print) / ISSN: 2528-5173 (Online)

Doi: $10.25273 /$ pe.v11i2.9658

The article is published with Open Access at: http://e-journal.unipma.ac.id/index.php/PE

\title{
Effectivity of interactive multimedia with theocentric approach to the analytical thinking skills of elementary school students in science learning
}

\author{
Azmil Hasan Lubis $\bowtie$, Universitas Islam Negeri Ar-Raniry Banda Aceh \\ Febrianawati Yusup, Universitas Islam Negeri Antasari Banjarmasin \\ Muhammad Darwis Dasopang, Institut Agama Islam Negeri Padangsidimpuan \\ Sapitri Januariyansah, Universitas Negeri Medan \\ $\bowtie$ azmilhasan.lubis@ar-raniry.ac.id
}

\begin{abstract}
This study aims to analyze the effectivenessof interactive multimedia with the theocentric approach on the analytical thinking skills of elementary school students in science learning. This study used a quantitative approach with a quasi-experimental type. The sampling technique used random cluster sampling with 67 students. The data were collected through analytical thinking skills tests given before and after science learning. The data analysis technique used descriptive and inferential statistics analysis by comparing the increase in the average results of the test and t-test. The research results show that the average value of students' analytical thinking skills in the experimental class is higher, which is an increase of $44.74 \%$ compared to the control class which only increases by $17.20 \%$. The results of the t-test also show a significant effect between interactive multimedia with theocentric approach on students' analytical thinking skills with a significance value of $0.00(<0.05)$. Therefore, interactive multimedia with the theocentric approach is effectively used to improve the analytical thinking skills of elementary school students in science learning.
\end{abstract}

Keywords: Interactive Multimedia, Theocentric, Analytical Thinking Skills, Science Learning.

Received 25 June 2021; Accepted 18 August 2021; Published 01 December 2021

Citation: Lubis, A. H., Yusup, F., Dasopang, M.D., \& Januariyasah, S. (2021). Effectivity of interactive multimedia with theocentric approach to the analytical thinking skills of elementary school students in science learning. Premiere Educandum : Jurnal Pendidikan Dasar dan Pembelajaran, 11(2), c. Doi.org/10.25273/pe.v11i2.9658

\section{(c) BY-NC-SA}

Published by Universitas PGRI Madiun. This work is licensed under the Creative Commons Attribution-NonCommercialShareAlike 4.0 International License. 


\section{INTRODUCTION}

The 21st century promises to be a big challenge that significantly impacts the current direction of education and learning (Lubis \& Dasopang, 2021; Zamaludin, Yusnaeni, \& Amelia, 2016). This also has an impact on the demands on teachers to be able to teach special abilities that students can use in dealing with technological developments in the 21st century (Soh, Arsad, \& Osman, 2010). Currently, elementary school students are directed to have higher-order thinking skills including, critical, analytical, creative, logical, reflective, and metacognitive thinking skills (Fanani \& Kusmaharti, 2018; Usmaedi, 2017). The developing learning paradigm makes the learning process not enough to be able to form students to be able to answer the question "What?", more than that the learning process must form students to be able to answer the question "Why?" and how?". This ability is part of the ability to think analytically.

Analytical thinking is an essentialcompetency mastered by students to connect and find correlations from several concepts (Dafrita, 2017). The analytical thinking ability in science learning in elementary schools has a significant role where the students will more easily understand science learning materials through the procedure of connecting and comparing the causes and effects of a phenomenon (McDonald, 2012). The analytical thinking ability indicator used in this study refers to the opinion of Brookhart (2010) which states that the students who have good analytical thinking skills must be able to (1) find the reason why you have to choose one answer in solving the problem; (2) conduct an evaluation process on the conclusions determined through the investigation process; (3) make a hypothesis or a tentative answer through accurate and reliable information; (4) consider the validity of arguments through a deductive and inductive thinking process; (5) find supporting data to state that the method taken to resolve the amslaah is appropriate. The analytical thinking skills are part of higher-order thinking skills (HOTS) which are very suitable for elementary school students (Usmaedi, 2017). The analytical thinking ability measured in this study is the analytical thinking ability of elementary school students in science learning. The use of learning media is one way that teachers can achieve learning objectives, especially for elementary school students in the concrete operational stage (Pane \& Dasopang, 2017; Santrock, 2011; Wolfolk, 2016).

The learning media is a tool used as an intermediary by the teacher to assist in explaining an abstract concept to students in the learning process (Heinich, Molenda, Russell, 2002). Furthermore, Arsyad (2011) states that there are at least 6 functions of learning media, namely (1) Attracting students' attention; (2) Helping students understand the material taught by the teacher clearly; (3) Help overcome the limitations of space, time, and cost; (4) Minimize the possibility of misinterpretation of the material presented; (5) Accommodating a variety of learning styles owned by students; and (6) Helping the achievement of learning objectives. The findings of Portanata et al. (2017) stated that learning media is a need that must be met in science learning to make it easier for students to understand the science materials being taught. From this explanation, learning media is an essential part of being provided by the teacher in carrying out a learning process.

many studies prove the role of learning media in a learning process, including Lubis \& Wangid (2019) research which states that augmented reality-assisted learning media for picture storbooks can help shape student attitudes. Rohmantoro, Januariyansah, \& Yulanto (2020) also stated that learning media can improve student learning outcomes. In line with these findings, Yunita \& Wijayanti (2017) stated that learning media in the form of learning videos could improve student learning outcomes. Furthermore, Astuti \& Mustadi (2014) stated that animated film learning media can help students to improve students' writing skills. From these various studies, it can be concluded that learning media can play a role in helping improve students' cognitive (knowledge), affective 
(attitudes), and psychomotor (skills) aspects. These three aspects are the main goals of a learning process (Suprijono, 2012).

The development of technology is currently growing very fast. These technological developments have impacted on almost all aspects of life, including the aspects of education and learning. One of the impacts given by technological developments in education and learning is the creation of technology-based learning media that can make it easier for teachers to provide an understanding of the material to students and make students more interested in participating in the learning process (Yazdi, 2012). Interactive multimedia is an example of the transformation of learning media that is influenced by technological developments. interactive multimedia is a combined media of several controlling devices that allows interaction between the user and the media through the operation of the system by the users, where the user can browse on the media(Istiqlal, 2017). One of the applications that can be used in developing interactive multimedia is Adobe Flash because in addition to being able to insert learning materials, it can also insert interesting animations (Rezeki, 2018).

Furthermore, animations in interactive multimedia can be presented creatively with the help of technology to attract the attention of students as users when using them (Koesnandar, 2019). The students' interest in the interactive multimedia used will impact on increasing their motivation when participating in the learning process (Irawan \& Suryo, 2017). The interactive multimedia can of course be combined with various approaches to help teachers and students achieve certain learning goals, one of which is to combine it with the Theocentric approach.

Theocentric is linguistically derived from 2 words:Theos (Greek) which means God and Centric (English) which means Center, so Theocentric means something centered on and on God. Theocentric in terms means a view that believes that everything in the universe comes from God and will eventually return to God (Peckham, 2014). Furthermore, Speaks (2020) explains that when viewed from an approach, the Theocentric concept means a point of view that focuses on inculcating divine values and beliefs so that moral messages can be appropriately conveyed.. Based on this explanation, interactive multimedia with the Theocentric approach referred to in this study is a learning media developed utilizing technology in Adobe Flash application by inserting content about moral values and belief in God. The content in question is the verses of the Qur'an related to the knowledge or material being taught, so that a paradigm is that everything in this world has been planned by Allah and that plan is written in the holy book of the Qur'an.

The several previous studies have examined the use of interactive multimedia in the learning process, including research conducted by Septian (2019) which found that interactive multimedia based on the Learning Cycle can help to improve student learning outcomes. Another study by Farid \& Lenny (2017) explains in its findings that interactive multimedia can significantly affect students' generic science skills. Furthermore, Husein, Herayanti, \& Gunawan (2017) stated through heir research that interactive multimedia has a significant influence on students' conceptual understanding and critical thinking skills. This research is present by bringing a novelty to the variables used. The interactive multimedia in this research is interactive multimedia which is integrated with the Theocentric approach. The interactive multimedia was then tested for its effect on students' analytical thinking skills in science learning at the elementary school level. To facilitate understanding of the flow and procedures of this research, the next section will discuss research methods. 


\section{METHODS}

\section{Research Design}

This study analyzes the effectiveness of using interactive multimedia with the Theocentric approach on the analytical thinking skills of elementary school students in science learning. The variables of this research were the interactive multimedia with theocentric approach (independent variable) and the analytical thinking ability (dependent variable). This study used a quantitative approach with a quasi-experimental type. The experimental design used in this study is the Pretest-Posttest Control Group Design (Johnson \& Christensen, 2014). The following is a picture of the experimental design used in this study.

\begin{tabular}{llll} 
Class & Pretest & Treatment & Posttest \\
\hline Experimental & $\mathrm{O}_{1}$ & $\mathrm{X}_{1}$ & $\mathrm{O}_{2}$ \\
\hline Control & $\mathrm{O}_{3}$ & $\mathrm{X}_{2}$ & $\mathrm{O}_{4}$ \\
\hline
\end{tabular}

FIGURE 1. Research design

Information:

$\mathrm{O}_{1}$ : condition of the experimental class before being given treatment

$\mathrm{O}_{2}$ : condition of the experimental class after being given treatment

$\mathrm{X}_{1}$ : Treatment in the experimental class

$\mathrm{X}_{2}$ : Treatment of the control class

$\mathrm{O}_{3}$ : condition of the control class before being given treatment

$\mathrm{O}_{4}$ : condition of control class after being given treatment

\section{Research Sample}

This research was conducted in Padangsidimpuan, North Sumatra, Indonesia. The population of this study were all state elementary school students in Padangsidimpuan. The samples involved in this study were fifth grade students of SD Negeri 15 and SD Negeri 12 Padangsidimpuan city which consisted of 67 students. The sampling technique used was the cluster random sampling technique. The sample was divided into 2 classes, namely 35 students into the experimental class and 32 students into the control class. The experimental class was made into a group that carried out science learning using the interactive multimedia with the Theocentric approach, while the control class did not use the interactive multimedia with the Theocentric approach. The following Table 1 summarizes the samples involved in this study.

TABLE 1. Summary of research sample

\begin{tabular}{lcccc}
\hline \multirow{2}{*}{ Class } & \multirow{2}{*}{ Amount } & \multirow{2}{*}{ Average age } & \multicolumn{2}{c}{ Gender } \\
\cline { 4 - 5 } & & & Man & Woman \\
\hline Experiment & 35 & 10.89 & 16 & 19 \\
Control & 32 & 10.91 & 12 & 20 \\
\hline
\end{tabular}

\section{Research Procedure}

This study used several procedures; the first step was to conduct a preliminary study that aimed to obtain initial research data in the form of problems in the field. Furthermore, 
after the initial research data and literature review were fulfilled, a research instrument was prepared, which were used to collect research dataThe compiled research instrument was a test instrument that measured the level of students' analytical thinking skills. After that, research data was collected by conducting pre-test and post-test in the experimental class (using interactive multimedia with the Theocentric approach) and control class (not using interactive multimedia with the Theocentric approach). After the research data was obtained, the assumption test is carried out, namely testing the normality and homogeneity of the data provided that if the data was normal and homogeneous, the analysis could be continued with parametric statistical tests. After the data was declared normal and homogeneous, then descriptive statistical tests were carried out to measure the average and increase in the average analytical thinking ability test results of students in the experimental class and control class. The next step was to test the research hypotheses with parametric statistical tests using independent t-tests to obtain the significance value of the effectiveness of interactive multimedia with the Theocentric approach. Finally, after all was done, the conclusion of the research was drawn.

\section{The Data Collection and Analysis}

The data obtained in this study was quantitative data collected using an analytical thinking ability test instrument in essay test format. This test instrument was used to measure the analytical thinking ability of elementary school students in science learning. This instrument was given before and after (pre-post) treatment. The following is a grid of research instruments used in this study.

TABLE 2. Research instruments grid

\begin{tabular}{|c|c|}
\hline Aspect & Indicator \\
\hline $\begin{array}{l}\text { Find the reason of the } \\
\text { argument }\end{array}$ & $\begin{array}{l}\text { Students find reasons for expressing arguments against an } \\
\text { answer }\end{array}$ \\
\hline $\begin{array}{l}\text { Carry out the observation } \\
\text { process }\end{array}$ & Students find solutions to the problems they face \\
\hline Formulate a hypothesis & $\begin{array}{l}\text { Students make a temporary answer to a problem through a } \\
\text { literature review }\end{array}$ \\
\hline Testing a truth & Students test the truth of a fact or problem \\
\hline Looking for valid evidence & $\begin{array}{l}\text { Students find appropriate evidence by comparing science } \\
\text { with verses in the Qur'an }\end{array}$ \\
\hline
\end{tabular}

The data obtained were then analyzed by descriptive statistical techniques by analyzing each test's average. The average analysis process was carried out by comparing the average pre-test score with the post-test average between the experimental and control classes Then, a t-test was performed to find the different values. The t-test was used because the number of classes involved in this study was only 2, namely the experimental class and the control class, so the t-test was an appropriate analysis to use (Sugiyono, 2016). There are 2 t-tests used in this study, namely paired t-test and independent t-test. Paired t-test was conducted to find the difference in analytical thinking ability of experimental class students between before and after being given treatment. The data used for this paired t-test analysis was the pre-test and post-test scores in the experimental class. After that, an independent t-test was conducted to analyze the different values of analytical thinking skills between students in the experimental class who used interactive multimedia with the Theocentric approach and students in the control class who did not use it. The data used for this independent t-test analysis was the post-test value of the experimental and control class students. The SPSS 22.0 application for windows assisted the entire process of data analysis in this study. 


\section{RESULTS}

\section{Comparison of Average Test Results}

The results showed that interactive multimedia with the Theocentric approach is effectively used to improve the analytical thinking skills of elementary school students in science learning. It can be seen from the results of the analysis of the analytical thinking ability test data conducted before and after being given treatment, showing an increase in the average in the experimental class. Analysis of the analytical thinking ability test data in this study is carried out in two stages, namely (1) descriptive statistical test by comparing the average score and the percentage increase in the average score of the pre-test with the post-test in the experimental class; and (2) inferential statistical test by performing a different test using an independent t-test technique. The results of descriptive statistical tests on analytical thinking ability test data will be presented in Table $\mathbf{3}$.

TABLE 3. Descriptive analysis of analytical thinking ability test

\begin{tabular}{lccc}
\hline \multirow{2}{*}{ Class } & \multicolumn{2}{c}{ Average Score } & \multirow{2}{*}{ \% Increase in Average Score } \\
\cline { 2 - 3 } & Pre-test & Post-test & \\
\hline Experiment & 50.67 & 78.33 & $44.74 \%$ \\
Control & 52.33 & 61.33 & $17.20 \%$ \\
\hline
\end{tabular}

The data presented in Table 3 shows that the average pre-test scores of students' analytical thinking skills in the experimental and control classes are 50.67 and 52.33, respectively. This means that it can be concluded that the analytical thinking skills of students in the experimental class and control class before being given treatment tend to be the same because there is no significant difference in the average value. However, after the treatment is carried out by carrying out the learning process using interactive multimedia with the Theocentric approach in the experimental class, there is an increase in the average value of the analytical thinking ability test results. The the post-test's result in the experimental class showed that the average value of the experimental class was 78.33. While in the control class, the learning process is carried out but did not use interactive multimedia with the Theocentric approach;the post-test results show the average value of students' analytical thinking skills was 61.33.

The test results of the two classes increased when compared to the average value of the pre-test and post-test. However, if it is reviewed more specifically by comparing the increase in the average between the two classes, it is clear that the increase in the average value in the experimental class has increased more significantly than in the control class. This can also be seen in the data presented in Table $\mathbf{3}$ which shows that the percentage increase in the average score of the analytical thinking ability test of students in the experimental class is $44.74 \%$, while the increase in the average score of the analytical thinking ability test of students in the control class is $17.20 \%$. Based on these data, it shows that interactive multimedia with the Theocentric approach significantlyinfluences on students' analytical thinking skills in science learning.

\section{Normality and Homogeneity Test}

The results of the students' analytical thinking ability test are also analyzed using an independent t-test technique. However, before the independent t-test is conducted, the assumption test is conducted on the students' analytical thinking ability test results. The assumption test carried out is the normality test of the data and the homogeneity test. The following Table 4 presents the results of the normality test of the data in this study. 
TABEL 4. Data normality test results

\begin{tabular}{|c|c|c|c|c|}
\hline Class & $\begin{array}{l}\text { Type of } \\
\text { Test }\end{array}$ & $\begin{array}{c}\text { P Value } \\
\text { Kolmogrov-Smirnov }\end{array}$ & Assumption & Information \\
\hline \multirow{2}{*}{ Experiment } & Pre-test & 0.21 & $\mathrm{P}>0.05$ & Normal \\
\hline & Post-test & 0.29 & $\mathrm{P}>0.05$ & Normal \\
\hline \multirow{2}{*}{ Control } & Pre-test & 0.15 & $P>0.05$ & Normal \\
\hline & Post-test & 0.20 & $P>0.05$ & Normal \\
\hline
\end{tabular}

Table 4 shows that all the data from the students' analytical thinking ability test results in this study are normal data. This can be seen from the Kolmogrov-Smirnov $P$ value, all the tests carried out showed a value greater than the assumed value $(P>0.05)$, which means that all data are declared to be normally distributed. The results of the homogeneity test also show that the data comes from a homogeneous population. It can be proven through the results of the homogeneity test, which shows that the significance value (Based on mean) is 0.086 ( $>0.05$ ), which means that the data comes from a homogeneous population. The normality and homogeneity tests that show that the data are normally distributed and come from a homogeneous population lead to a conclusion that the assumption test results have met the requirements for parametric statistical testing with independent t-test techniques.

\section{T-Test}

The t-test in this study is conducted to find the significance of the different treatment values. There are two types of t-test, namely paired $t$-test and independent $t$-test. Paired $t-$ test in this study is used to determine whether there were differences in students' analytical thinking skills between before and after participating in science learning using interactive multimedia with a Theocentric approach. The pre-test and post-test scores in the experimental class are used in this paired t-test stage. Paired t-test results show that the significance value is $0.00(<0.05)$. These results mean that the hypothesis is accepted, which means that there are differences in students' analytical thinking abilities before and after participating in science learning using interactive multimedia with a Theocentric approach. Then, an independent t-test was performed.

The independent t-test in this study is conducted to determine whether there is a difference in analytical thinking skills between the experimental class who participated in science learning using interactive multimedia with the Theocentric approach and the control class that carried out science learning without using the interactive multimedia. The results of the independent t-test in this study can be seen in Table 5 below.

TABLE 5. Independent t-test results

\begin{tabular}{lccc}
\hline \multirow{2}{*}{ Variable } & \multicolumn{2}{c}{ Equal Variances Assumed } & Information \\
\cline { 2 - 3 } & $\begin{array}{c}\text { Value } \\
\text { Significance }\end{array}$ & Assumption & \\
\hline Analytical Thinking Ability & 0.00 & $<0.05$ & There's a difference \\
\hline
\end{tabular}

The data presented in Table 5 shows that the independent t-test results in the experimental class and control class are $0.00(<0.05)$. These results mean that the hypothesis accepted in this test is that there are differences in the analytical thinking abilities of students who take science learning using interactive multimedia with the Theocentric approach (experimental class) with students who take science lessons not using interactive multimedia with Theocentric approach (control class). 


\section{DISCUSSION}

The ability to think analytically is the dependent variable tested in this study using interactive multimedia with the Theocentric approach as the independent variable. Indicators of analytical thinking skills used in this study are 1) Finding reasons for arguments; 2) Conducting the observation process; 3) Developing a hypothesis; 4) Testing a truth; and 5) Looking for valid evidence. This is in accordance with the opinion of Robbins (2011) which states that students who have good analytical thinking skills can be seen from their ability to provide clear arguments against the opinions or answers submitted. The process of compiling the argument is of course after going through observation and truth testing so that a temporary answer is formed that is used to solve a problem (Wolfe, Christensen, \& Vandervelde, 2020). Furthermore, Ilma et al. (2017) stated that students who think analytically couldexplain their arguments verbally and visually.

The interactive multimedia in this study is applied to science learning in elementary schools. The interactive multimedia is created with the help of the Macromedia Flash application, then combined with the Theocentric approach. Kusumawati (2016) states that interactive multimedia Macromedia Flash is one of the effective multimedia used in science learning in elementary schools. Interactive multimedia with the Theocentric approach in this study has a significant influence on the analytical thinking skills of elementary school students in science learning through several components in it, namely 1) presentation of interesting material; 2) the use of the verses of the Qur'an in the material presented; and 3) ability test facility. The material presented in this interactive multimedia is material on the solar system. The material discusses starting from the sun as the center of the solar system, the 9 planets surrounding, satellites and other celestial bodies. The material is displayed more attractively in this interactive multimedia by using attractive images. In addition to images, this interactive multimedia also has interesting animations to attract students' attention and increase student motivation in learning. This is in accordance with Dewi \& Haryanto (2019) findings which states that the use of animations in interactive multimedia can foster the learning spirit of elementary school students. Furthermore, good learning motivation is essential in the science learning process at the elementary school level so that student learning outcomes can increase (Hamdu \& Agustina, 2011), on the other hand, analytical thinking ability is one part of the goals of a learning process (Radmehr \& Drake, 2019).

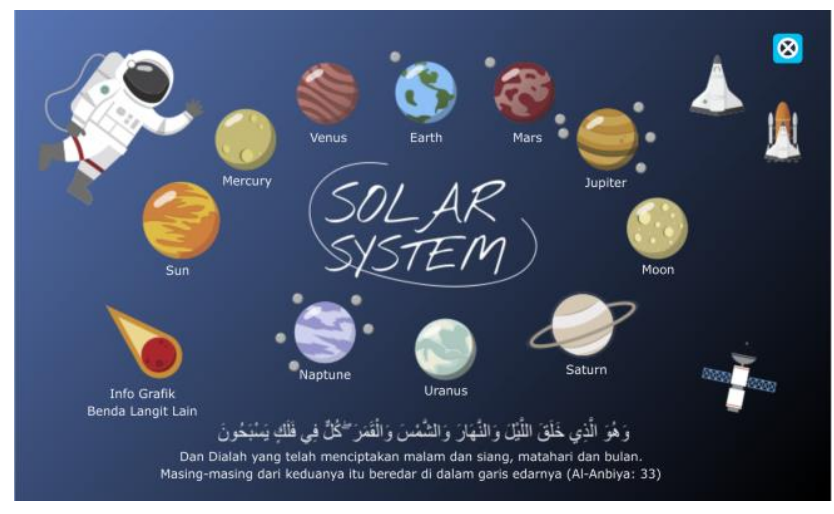

FIGURE 2. Material Animation Display

The material presented in interactive multimedia with this Theocentric approach also helps students to develop their ability to analyze because the material is juxtaposed with the verses of the Qur'an. The pairing is made so that students can compare, test, and observe the harmony between the science researched by humans and the Qur'an which is the word of Allah the Almighty. Lakeh \& Ghaffarzadegan (2015) state that analysis is carried out by comparing literature or facts to obtain a conclusion. In line with this 
opinion, Jolley et al. (2016) stated that the analytical thinking process requires students to look for supporting facts to answer the compiled hypothesis. Furthermore, the inclusion of the content of the Qur'anic verses related to the material can make students understand that everything in science comes from God and God has arranged all natural phenomena that have occurred, this concept is called Theocentric that all originates or is centered on God (Gufron, 2018).

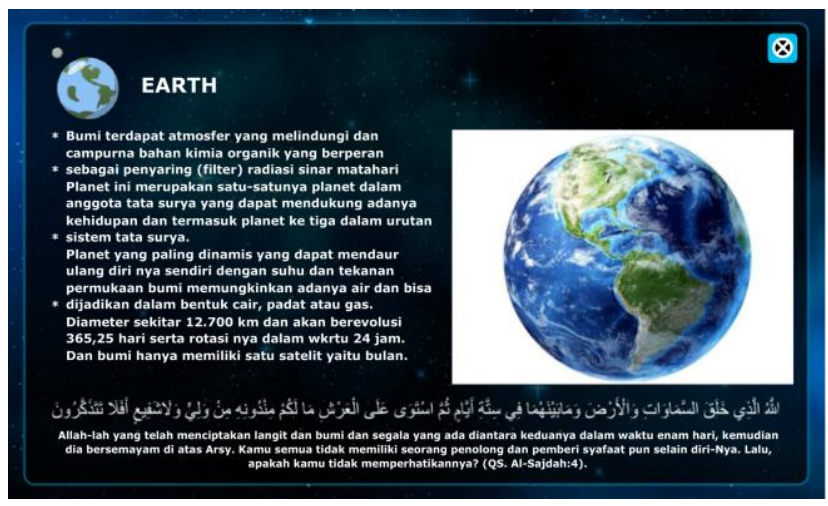

FIGURE 3. Relation of Verses to Material

The interactive multimedia with the Theocentric approach in this study was also given practice questions about the material presented to practice their analytical thinking skills. Good learning media must have components that can help students achieve learning goals, one of which is the addition of practice questions as media component (Lubis \& Dasopang, 2020; Waluyo, Bintang, \& Januariyansah, 2021). Giving practice questions can help teachers measure students' ability to understand the material being taught and help students recall the material they have obtained so that learning outcomes can improve (Lubis, 2019). Furthermore, practice questions can also be used as a medium in training students' analytical thinking skills by providing questions that require problem-solving skills (Ikhwanuddin, 2010). The problem-solving process will hone students' ability to analyze problems to find the right solution to solve the problem (Hasyim, 2018).

\section{CONCLUSION}

This study indicates that interactive multimedia with the Theocentric approach is effective and has a significant influence on the analytical thinking skills of elementary school students in science learning. It is evidenced by the increase in the average value in the experimental class, which is higher than the control class, which does not use tmultimedia in science learning. The results of the different tests also prove differences in analytical thinking skills between students who take science learning using interactive multimedia with the Theocentric approach and students who do not use interactive multimedia with the Theocentric approach. This research is expected to contribute by becoming a reference for the development of science in the future, especially science education and learning at the elementary school level. However, this study has limitations on variables because the variables tested are only on analytical thinking skills. Future research is expected to test the effectiveness of interactive multimedia with the Theocentric approach on other variables.

\section{REFERENCES}

1. Arsyad, A. (2011). Media Pembelajaran. Jakarta: PT Raja Grafindo Persada.

2. Astuti, Y. W., \& Mustadi, A. (2014). Pengaruh Penggunaan Media Film Animasi terhadap Keterampilan Menulis Karangan Narasi Siswa Kelas V SD. Jurnal Prima 
Edukasia, 2(2), 250-262.

3. Baghaei Lakeh, A., \& Ghaffarzadegan, N. (2015). Does analytical thinking improve understanding of accumulation? System Dynamics Review, 31(1-2), 46-65.

4. Brookhart, S. M. (2010). How to Assess Higher-Order Thinking Skills in Your Classroom. Alexandria: ASCD.

5. Dafrita, I. E. (2017). Pengaruh Discovery Learning terhadap Kemampuan Berpikir Kritis dan Analitis dalam Menemukan Konsep Keanekaragaman Tumbuhan. Jurnal Pendidikan Informatika Dan Sains, 6(1), 32-46.

6. Dewi, S. R., \& Haryanto, H. (2019). Pengembangan Multimedia Interaktif Penjumlahan pada Bilangan Bulat untuk Siswa Kelas IV Sekolah Dasar. Premiere Educandum: Jurnal Pendidikan Dasar Dan Pembelajaran, 9(1), 9-22.

7. Fanani, A., \& Kusmaharti, D. (2018). Pengembangan Pembelajaran berbasis HOTS (Higher Order Thinking Skill) di Sekolah Dasar Kelas V. Jurnal Pendidikan Dasar, 9(1), 1-11.

8. Farid, M., \& Leny, L. (2017). Pengaruh Model Pembelajaran Problem Solving Berbantuan Multimedia Interaktif terhadap Keterampilan Generik Sains dan Hasil Belajar Siswa pada Materi Hidrolisis Garam. QUANTUM: Jurnal Inovasi Pendidikan Sains, 7(1), 10-18.

9. Gufron, M. (2018). Transformasi Paradigma Teologi Teosentris menuju Antroposentris: Telaah atas pemikiran Hasan Hanafi. Millati: Journal of Islamic Studies and Humanities, 3(1), 141-171.

10. Hamdu, G., \& Agustina, L. (2011). Pengaruh Motivasi Belajar Siswa terhadap Prestasi Belajar IPA di Sekolah Dasar. Jurnal Penelitian Pendidikan, 12(1), 90-96.

11. Hasyim, F. (2018). Mengukur Kemampuan Berpikir Analitis dan Keterampilan Proses Sains Mahasiswa Calon Guru Fisika STKIP Al Hikmah Surabaya. JIPVA Ournal Pendidikan IPA Veteran), 2(1), 80-89.

12. Husein, S., Herayanti, L., \& Gunawan, G. (2017). Pengaruh Penggunaan Multimedia Interaktif terhadap Penguasaan Konsep dan Keterampilan Berpikir Kritis Siswa pada Materi Suhu dan Kalor. Jurnal Pendidikan Fisika Dan Teknologi, 1(3), 221-225.

13. Ikhwanuddin, I. (2010). Problem Solving dalam Pembelajaran Fisika untuk Meningkatkan Kemampuan Mahasiswa Berpikir Analitis. Jurnal Kependidikan: Penelitian Inovasi Pembelajaran, 40(2), 215-230.

14. Ilma, R., Hamdani, A. S., \& Lailiyah, S. (2017). Profil Berpikir Analitis Masalah Aljabar Siswa Ditinjau dari Gaya Kognitif Visualizer dan Verbalizer. JRPM (Jurnal Review Pembelajaran Matematika), 2(1), 1-14.

15. Irawan, E., \& Suryo, T. (2017). Implikasi Multimedia Interaktif berbasis Flash terhadap Motivasi dan Prestasi Belajar Matematika. Beta: Jurnal Tadris Matematika, 10(1), 33-50.

16. Istiqlal, M. (2017). Pengembangan Multimedia Interaktif dalam Pembelajaran Matematika. JIPMat, 2(1), 43-54.

17. Johnson, R. B., \& Christensen, L. (2014). Educational Research: Qualitative, Quantitative, and Mixed Approaches. (5, Ed.). Los Angeles: Sage Publication.

18. Jolley, D. F., Wilson, S. R., Kelso, C., O’Brien, G., \& Mason, C. E. (2016). Analytical Thinking, Analytical Action: Using Prelab Video Demonstrations and E-quizzes to Improve Undergraduate Preparedness for Analytical Chemistry Practical Classes. Journal of Chemical Education, 93(11), 1855-1862.

19. Koesnandar, A. (2019). Pengembangan Software Pembelajaran Multimedia Interaktif. Jurnal Teknodik, 10(18), 75-88. https://doi.org/http://dx.doi.org/10.32550/teknodik.v0i0.548

20. Kusumawati, N. (2016). Pengembangan Media Pembelajaran IPA dengan animasi Macromedia Flash berbasis Model Pengajaran Langsung (Direct Instruction) di Sekolah Dasar. Premiere Educandum: Jurnal Pendidikan Dasar Dan Pembelajaran, 5(2), 263-271.

21. Lubis, A. H. (2019). Upaya Peningkatan Hasil Belajar Siswa Sekolah Dasar melalui 
Model Cooperative Learning Tipe Numered Heads Together. FORUM PAEDAGOGIK, 11(2), 127-143.

22. Lubis, A. H., \& Dasopang, M. D. (2020). Pengembangan Buku Cerita Bergambar Berbasis Augmented Reality untuk Mengakomodasi Generasi Z. Jurnal Pendidikan: Teori, Penelitian, Dan Pengembangan, 5(6), 780-791.

23. Lubis, A. H., \& Dasopang, M. D. (2021). Online Learning during the Covid-19 Pandemic: How is It Implemented in Elementary Schools? Premiere Educandum: Jurnal Pendidikan Dasar Dan Pembelajaran, 11(1), 120-134.

24. Lubis, A. H., \& Wangid, M. N. (2019). Augmented Reality-assisted Pictorial Storybook: Media to Enhance Discipline Character of Primary School Students. Mimbar Sekolah Dasar, 6(1), 11-20. https://doi.org/10.17509/mimbar-sd.v6i1.16415

25. McDonald, G. (2012). Teaching Critical \& Analytical Thinking in High School Biology? The American Biology Teacher, 74(3), 178-181.

26. Pane, A., \& Dasopang, M. D. (2017). Belajar dan Pembelajaran. Fitrah: Jurnal Kajian Ilmu-Ilmu Keislaman, 3(2), 333-352.

27. Peckham, J. C. (2014). Does God Always Get What He Wants? A Theocentric Approach to Divine Providence and Human Freedom. Andrews University Seminary Studies (AUSS), 52(2), 195-212.

28. Portanata, L., Lisa, Y., \& Awang, I. S. (2017). Analisis Pemanfaatan Media Pembelajaran IPA SD. JURNAL PENDIDIKAN DASAR PERKHASA: Jurnal Penelitian Pendidikan Dasar, 3(1), 337-348.

29. R. Heinich, M. Molenda, J. D. Russell, S. E. S. (2002). Instructional Media and Technologies for Learning (7th ed.). New Jersey: Merill Prentice Hill.

30. Radmehr, F., \& Drake, M. (2019). Revised Bloom's Taxonomy and Major Theories and Frameworks that Influence The Teaching, Learning, and Assessment of Mathematics: A Comparison. International Journal of Mathematical Education in Science and Technology, 50(6), 895-920.

31. Rezeki, S. (2018). Pemanfaatan Adobe Flash CS6 berbasis Problem based Learning pada Materi Fungsi Komposisi dan Fungsi Invers. Jurnal Pendidikan Tambusai, 2(2), 856-864.

32. Robbins, J. K. (2011). Problem Solving, Reasoning, and Analytical Thinking in A Classroom Environment. The Behavior Analyst Today, 12(1), 41-48.

33. Rohmantoro, D., Januariyansah, S., \& Yulanto, D. M. (2020). Pengaruh Media Pembelajaran dan Kecerdasan Emosional terhadap Hasil Belajar Siswa Sekolah Menengah Kejuruan. Journal of Automotive Technology Vocational Education, 1(1), 3339.

34. Santrock, J. W. (2011). Educational Psychology (5th ed.). New York: McGraw-hill Companies.

35. Septian, D. (2019). Pengaruh Multimedia Interaktif berbasis Learning Cycle terhadap Hasil Belajar Siswa. Jurnal Pendidikan Fisika Dan Sains (JPFS), 2(1), 6-16.

36. Soh, T. M. T., Arsad, N. M., \& Osman, K. (2010). The Relationship of 21st Century Skills on Students' Attitude and Perception towards Physics. Procedia-Social and Behavioral Sciences, 7, 546-554.

37. Speaks, J. B. (2020). Piety and Theocentric Naturalism. Toronto Journal of Theology, $36(1), 14-23$.

38. Sugiyono. (2016). Metode Penelitian Pendidikan: Pendekatan Kuantitatif, Kualitatif, dan $R \& D$. Bandung: Alfabeta.

39. Suprijono, A. (2012). Cooperative Learning: Teori dan Aplikasi Paikem. Yogyakarta: Pustaka Pelajar.

40. Usmaedi, U. (2017). Menggagas Pembelajaran HOTS pada Anak Usia Sekolah Dasar. JPsd (Jurnal Pendidikan Sekolah Dasar), 3(1), 82-95.

41. Waluyo, B. D., Bintang, S., \& Januariyansah, S. (2021). The Effect of Using Proteus Software as A Virtual Laboratory on Student Learning Outcomes. Paedagoria: Jurnal Kajian, Penelitian Dan Pengembangan Kependidikan, 12(1), 140-145. 
42. Wolfe, C. J., Christensen, B. E., \& Vandervelde, S. D. (2020). Intuition Versus analytical Thinking and Impairment Testing. Contemporary Accounting Research, 37(3), 15981621.

43. Wolfolk, A. (2016). Educational Psychology (13th ed.). Boston: Pearson Education Inc.

44. Yazdi, M. (2012). E-learning sebagai Media Pembelajaran Interaktif berbasis Teknologi Informasi. Jurnal Ilmiah Foristek, 2(1), 143-152.

45. Yunita, D., \& Wijayanti, A. (2017). Pengaruh Media Video Pembelajaran terhadap Hasil Belajar IPA Ditinjau dari Keaktifan Siswa. Sosiohumaniora: Jurnal Ilmiah Ilmu Sosial Dan Humaniora, 3(2), 153-160.

46. Zamaludin, I., Yusnaeni, W., \& Amelia, S. (2016). Perancangan Pembelajaran Jarak Jauh (E-learning). Jurnal PROSISKO, 3(2), 20-25.

\section{PROFILE}

Azmil Hasan Lubis is a lecturer at the Pendidikan Guru Madrasah Ibtidaiyah Study Program, Faculty of Tarbiyah and Teacher Training, Universitas Islam Negeri Ar-Raniry Banda Aceh. Active in various research and community service activities in the field of Primary Education.

Febrianawati Yusup is a lecturer at the Tadris Biologi Study Program, Faculty of Tarbiyah and Teacher Training, Universitas Islam Negeri Antasari Banjarmasin. Active in various research and community service activities in the field of Science.

Muhammad Darwis Dasopang is a lecturer at the Pendidikan Agama Islam Study Program, Faculty of Tarbiyah and Teacher Training, Institut Agama Islam Negeri Padangsidimpuan. He currently serves as Vice Chancellor for academic and institutional development at the Institut Agama Islam Negeri Padangsidimpuan. In addition, he is also active in various research and community service activities in the field of Islamic Education.

Sapitri Januariyansah is a lecturer at the Pendidikan Teknik Mesin Study Program, Faculty of Engineering, Universitas Negeri Medan. Active in various research and community service activities in the field of Mechanical Engineering and Learning Technology. 